\title{
Drying Kinetics of Eggplant (Solanum melongena) in a Fluidized Bed Dryer: Experimental Evaluation and Modelling
}

\author{
Mohamed A. ElKhodiry, Shaima R. Suwaidi, Melika Taheri, Hams Elwalid, \\ Dina ElBaba, and Muhammad Qasim
}

Department of Chemical Engineering, American University of Sharjah, P.O. Box 26666, Sharjah, UAE

Correspondence should be addressed to Muhammad Qasim; b00023217@aus.edu

Received 20 August 2015; Revised 15 October 2015; Accepted 20 October 2015

Academic Editor: Raquel P. Guiné

Copyright (C) 2015 Mohamed A. ElKhodiry et al. This is an open access article distributed under the Creative Commons Attribution License, which permits unrestricted use, distribution, and reproduction in any medium, provided the original work is properly cited.

\begin{abstract}
The drying kinetics of eggplant were studied experimentally in a laboratory-scale fluidized bed dryer. Experiments were conducted at drying temperatures of 60,70 , and $80^{\circ} \mathrm{C}$ and at constant air velocity of $3.10 \mathrm{~ms}^{-1}$. The drying rate and moisture ratio were determined as a function of time. At any given temperature, only the falling rate period was observed during the drying process. Effective moisture diffusivity was in the range $2.667-4.311 \times 10^{-8} \mathrm{~m}^{2} / \mathrm{s}$ while activation energy of $23.5 \mathrm{~kJ} \mathrm{~mol}^{-1}$ was obtained from the Arrhenius equation. The experimental moisture ratio data was fitted to ten mathematical models. Statistical analysis showed that the by Demir et al. has the best fit quality. In terms of product quality, the dried samples had low rehydration ratio of 4.889 . In addition, compared to direct sunlight drying, the dried product from the fluidized bed dryer exhibited better color quality.
\end{abstract}

\section{Introduction}

Drying, or dehydration, is an important industrial process that involves the removal of moisture from a wet solid by means of facilitated heat and mass transfer [1]. Dehydration is considered an important process in food process industries since it helps preserve food and improves food quality and hygienic conditions. This means that specific fruits and vegetables can be consumed throughout the year and acute shortages caused by the shift in agricultural seasons can be avoided [2]. Such an approach has been used for centuries by means of traditional sun-drying technique [3].

Dried fruits and vegetables are important for a number of reasons. For instance, apricots, raisins, dates, figs, and plums are consumed as dried fruits because they have nutritional benefits attributed to their low carbohydrate and fat content. In addition, dried vegetables such as onions and garlic are used mainly as flavor additives while other dried vegetables such as peas, carrots, celery, and corn are used as dried snacks [4]. Another important reason behind drying vegetables and fruits is to facilitate transportation and storage. Fresh raw fruits and vegetables are not easy to transport. However, drying these agricultural products under appropriate conditions makes the transportation process significantly easier without losing a noticeable amount of contained vitamins [3]. Drying also prevents microbial contamination by reducing the water activity of the fresh agricultural commodities [5]. In the presence of moisture, pathogens can colonize the fruits and vegetables, producing mycotoxins that possess a health hazard to consumers [2]. Furthermore, under optimized drying conditions and temperature, drying can also enhance the product quality [5].

Fluidized bed dryers have been widely used for drying various agricultural products such as apple $[6,7]$, olive pomace [8], canola [9], soybeans [10], castor oil seeds [11], bird's eye chilli [12], red bell pepper [13], carrots [14], black tea [15], baker's yeast [16], coconut [17], and hazelnut [18]. Fluidized bed drying, a technique that was originally adapted for catalytic cracking of crude oil, offers several advantages over other types of drying such as solar drying, freeze drying, osmotic dehydration, spray drying, and vacuum drying [19, 20]. The main advantage is the thorough mixing of solids in this drying process which results in efficient mass and heat transfer, thus leading to rapid and economic drying [21-25]. 
Furthermore, inherent characteristics such as temperature uniformity and ease of control make fluidized bed dryers highly suitable for drying heat-sensitive products [22, 23, 25]. Also, fluidized bed dryers allow for easy handling and transport of the dried products which makes them appropriate for industrial purposes [19]. The main limitations of fluidized bed drying include loss of product qualities such as color, texture, flavor, and nutrients [3]. However, such drawbacks can be avoided by using appropriate drying conditions.

Studying the drying kinetics and the drying rate of agricultural products is important in order to minimize energy consumption and, accordingly, the cost of the drying process by determining the optimum drying conditions [26]. Several factors affect drying rate during the falling rate period such as air temperature and velocity and shape of the material to be dried. However, the temperature of the air is considered to be the most important factor affecting the drying process [27]. Drying rate increases significantly with an increase in hot air temperature which subsequently decreases the drying time $[1,28,29]$. However, it is crucial to optimize the temperature to attain maximum drying without cooking the foods or causing case hardening and shrinkage [30]. In addition, several studies have shown pretreatment to be another important factor in decreasing the drying time $[31,32]$. Hot water blanching, pulsed electric field, and high-pressure treatment are among the existing methods of pretreatment that increase drying rate and improve the quality of the final dried product $[32,33]$. Pretreatment of the sample also increases the brightness of the dried sample [1]. This is an important consideration since the color of the dried fruit or vegetable has a primary role in the consumer's perception [34].

To accurately predict the drying kinetics, several drying models have been developed and used taking into consideration the aforementioned factors. Most of these models are based on the principle that the moisture gradient is the driving force in the drying process and, therefore, these models use the temperature-dependent diffusion equations and first-order rate kinetics [35]. The reliability of such models in predicting the drying curves of different vegetables has been confirmed elsewhere in the literature $[28,36]$.

Eggplant (Solanum melongena) is an important agricultural product that is cultivated on a large scale in various countries. According to statistics by the Food and Agricultural Organization (FAO) of the United Nations, the total production of eggplants in the year 2013 was approximately 49.4 million tons [37]. Among all the eggplant-producing countries, Spain, Mexico, and Netherlands represent the top three exporters of eggplants [38]. Drying of eggplants is important for ensuring easy shipment and yearlong use in regions such as the Middle East and for use as an ingredient in soups and sauces [39]. Drying kinetics of eggplant have already been investigated using convective hot air dryer [1, 40], cabinet dryer [41], vacuum dryer [42], and ultrasonically assisted convective drying [43]. However, fluidized bed drying characteristics of eggplant are not reported in the literature. The aim of this study was to study the drying behavior and the drying kinetics of eggplant in a laboratoryscale fluidized bed dryer. The effect of hot air temperature on drying rate and moisture ratio was investigated and the temperature-dependent effective moisture diffusivities were estimated using Fick's second law of diffusion. The experimental drying data was fitted to different mathematical models and, finally, rigorous statistical analysis was used to identify the best mathematical model.

\section{Materials and Methods}

2.1. Preparation of Eggplant Samples. The eggplants (Solanum melongena var. Black Enorma) used in this study were originally cultivated in Netherlands and obtained from a local supermarket in Sharjah, United Arab Emirates. After washing with tap water and allowing for stabilization at room temperature, the eggplants were peeled and then cut into $5.5 \mathrm{~mm}$ homogeneous cubes using a lab utility knife. The prepared samples were used for the drying experiments on the same day. The initial moisture content of the samples was obtained by averaging the initial moisture contents from all the experimental runs and was found to be $0.986 \mathrm{~kg} \mathrm{H}_{2} \mathrm{O} \mathrm{kg}^{-1}$ wet mass (98.6 wt.\% water).

2.2. Drying Equipment and Procedure. Drying experiments were performed in a laboratory-scale batch fluidized bed dryer (Model: FT-31, Armfield, UK). The cabinet of this dryer consists of an inlet air filter, an electrical heater, a two-term (PI) temperature controller, a sequence timer, and a centrifugal air blower fan. The heater is a simple finned element with $2 \mathrm{~kW}$ power rating. The temperature controller can be used to set the hot air inlet temperature between 20 and $200^{\circ} \mathrm{C}$ with an offset of $\pm 1^{\circ} \mathrm{C}$ over the entire operating range. The timer can be used for automatic drying cycles with duration up to $6 \mathrm{~h}$. The dryer also allows for varying the air velocity by means of a blower speed control graduated from 1 to 10 corresponding to air velocities from 1.80 to $3.65 \mathrm{~ms}^{-1}$. The drying chamber consists of a glass column, $16 \mathrm{~cm}$ in diameter and $25 \mathrm{~cm}$ in height, fitted with a filter bag over the top in order to retain the dried product. The base of the drying chamber consists of a nylon air distributor and stainless steel support gauze. The schematic diagram of the fluidized bed dryer is shown in Figure 1.

The samples were dried at hot air inlet temperatures of 60, 70 , and $80^{\circ} \mathrm{C}$. Exactly $14 \mathrm{~g}$ of freshly prepared eggplant sample was used for each experimental run. The mass was measured using a digital analytical balance (Model: WG5000, Adam Equipment, USA, accuracy of $\pm 0.1 \mathrm{~g}$ ). The same balance was used to measure the mass of the empty drying chamber along with the filter bag. For each run, the bed was fluidized at constant air velocity of $3.10 \mathrm{~ms}^{-1}$. The sample was placed in the drying chamber which was then covered with filter bag. The timer was set to $5 \mathrm{~min}$. After every five minutes, the dryer switched off automatically and the total mass of the drying chamber, filter bag, and the sample was measured within 10$15 \mathrm{~s}$. The drying process was then resumed. This procedure was repeated until the total mass of the drying chamber, filter bag, and the sample was constant; that is, the sample was completely dried. During the experiments, the ambient air temperature and the relative humidity varied in the ranges 


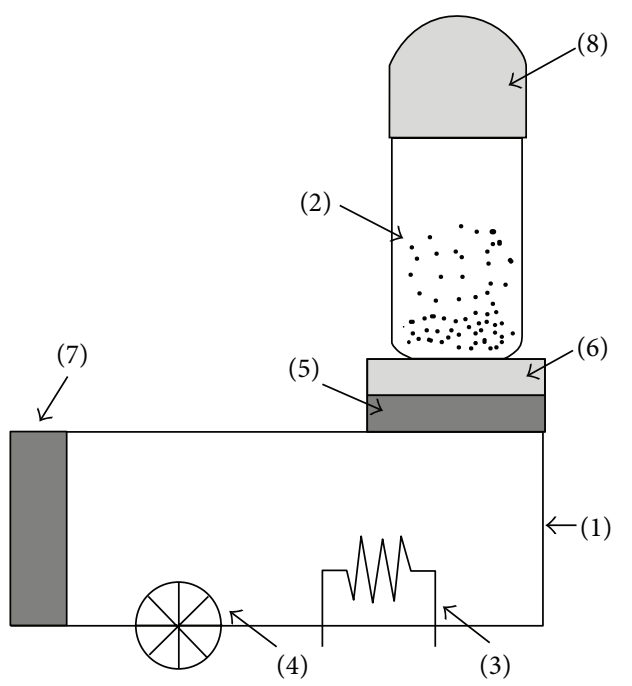

Figure 1: Schematic diagram of the experimental fluidized bed dryer. (1) Drying cabinet with timer, temperature controller, and on/off controls. (2) Fluidized drying chamber. (3) Electrical heater. (4) Blower. (5) Drying cabinet base. (6) Drying chamber base with air distributor and support gauze. (7) Inlet air filter. (8) Filter bag.

$22-23^{\circ} \mathrm{C}$ and $55-68 \%$, respectively. The mass of eggplant sample at any time inside the drying chamber was calculated by subtracting the mass of the empty drying chamber along with the filter bag from the total mass of the drying chamber, filter bag, and the sample. Each drying experiment was replicated three times and the average kinetic data for the three trials along with the standard error has been reported.

\subsection{Determination of Moisture Content and Moisture Ratio.} The moisture content $(X)$, expressed as $\mathrm{kg} \mathrm{H}_{2} \mathrm{O} \mathrm{kg}^{-1}$ dry mass, was calculated as a function of time using the following equation:

$$
X=\frac{m_{w}}{m_{d b}}=\frac{m_{s}-m_{d b}}{m_{d b}},
$$

where $m_{w}$ is the mass of water in the sample at any time $t$, $m_{d b}$ is the mass of the dried sample, and $m_{s}$ is the mass of the sample inside the drying chamber at time $t$.

The moisture ratio (MR) was then calculated by expressing the moisture content in the following dimensionless form:

$$
\mathrm{MR}=\frac{X-X_{e}}{X_{0}-X_{e}}
$$

where $X$ is the moisture content at any time $t, X_{0}$ is the initial moisture content, and $X_{e}$ is the equilibrium content.

2.4. Determination of Drying Rate. The drying rate (DR) was expressed as the amount of moisture lost by the sample over time. Mathematically, it can be expressed in $\mathrm{kg} \mathrm{H}_{2} \mathrm{O} \mathrm{kg}^{-1}$ dry mass $\min ^{-1}$ as follows:

$$
\mathrm{DR}=\frac{X_{t}-X_{t+d t}}{d t}
$$

where $X_{t}$ is the moisture content at times $t$ and $t+d t$, respectively, and $d t$ is the drying time.

2.5. Rehydration Test. In order to assess the quality of the dried eggplant samples, the rehydration ratio was determined by placing a sample of the product dried at $80^{\circ} \mathrm{C}$ in a beaker of deionized water for $24 \mathrm{~h}$. At the end of the test, excess water was drained and the mass of rehydrated sample was measured. The rehydration ratio (RR) was calculated as follows:

$$
\mathrm{RR}=\frac{m_{r}}{m_{d b}}
$$

where $m_{r}$ is the mass of the rehydrated eggplant sample and $m_{d b}$ is the mass of the dried sample used for rehydration.

Rehydration test was also performed by exposing another sample of the dried product to ambient moist air in the laboratory with relative humidity between 55 and 68\%. The test duration was again $24 \mathrm{~h}$.

2.6. Direct Sunlight Drying. For product quality comparisons, a fresh sample of eggplants was dried under direct sunlight. Exactly $14 \mathrm{~g}$ of fresh sample $(5.5 \mathrm{~mm}$ cubes) was placed under direct sunlight in a glass container. The highest and lowest ambient temperatures observed were 46 and $44^{\circ} \mathrm{C}$. Other observed climatic conditions were humidity of $16 \%$ and wind speed of $28 \mathrm{kmh}^{-1}$ (West) [44].

2.7. Estimation of Effective Moisture Diffusivity. The effective moisture diffusivities at different temperatures were calculated by applying Fick's second law of diffusion. This law has been widely accepted to describe the falling rate period of different agricultural products [45]. The general solution to this law is given below [46]:

$$
\mathrm{MR}=\frac{8}{\pi^{2}} \sum_{n=0}^{\infty} \frac{1}{(2 n+1)^{2}} e^{-(2 n+1)^{2} \pi^{2} D_{e} t / 4 L^{2}},
$$

where $t$ is the drying time (s), $D_{e}$ is the effective diffusivity $\left(\mathrm{m}^{2} / \mathrm{s}\right)$, and $L$ is half slab thickness of the eggplant cubes (m). Equation (5) is strictly true for cases where moisture movement is only by diffusion and external resistance is negligible. In addition, (5) assumes negligible shrinkage of the samples and constant diffusion coefficients and temperature [8].

For long periods of drying, (5) can be simplified by accounting only for the first term of the infinite series $[8,47]$. This simplification results in the following equations:

$$
\begin{aligned}
\mathrm{MR} & =\frac{8}{\pi^{2}} e^{-\pi^{2} D_{e} t / 4 L^{2}}, \\
\ln (\mathrm{MR}) & =\ln \left(\frac{8}{\pi^{2}}\right)-\frac{\pi^{2} D_{e} t}{4 L^{2}} .
\end{aligned}
$$

Equation (7) can be used to find the effective moisture diffusivity at any temperature from the slope of $\ln (\mathrm{MR})$ versus the drying time $t$ graph. 
In order to describe the effect of temperature on the effective moisture diffusivity, the following Arrhenius-type equation was used $[8,13]$ :

$$
D_{e}=D_{0} e^{-E_{a} / R T}
$$

where $D_{0}$ is the preexponential factor or the diffusivity at infinite temperature $\left(\mathrm{m}^{2} / \mathrm{s}\right), E_{a}$ is the activation energy $\left(\mathrm{kJ} \mathrm{mol}^{-1}\right), \quad R$ is the universal gas constant $\left(0.008314 \mathrm{~kJ} \mathrm{~mol}^{-1} \mathrm{~K}^{-1}\right)$, and $T$ is the absolute temperature (K).

2.8. Statistical Analysis of Drying Models. MS Excel was used to fit different mathematical models to the experiment moisture ratio data. In order to quantify the fit quality of the models, coefficient of determination $\left(R^{2}\right)$, reduced sum square error (SSE), root mean square error (RMSE), and reduced Chi-square $\left(\chi^{2}\right)$ were calculated for different mathematical models using the following equations:

$$
\begin{aligned}
R^{2} & =\left[\frac{n \sum_{i=1}^{n} \mathrm{MR}_{e, i} \cdot \mathrm{MR}_{m, i}-\sum_{i=1}^{n} \mathrm{MR}_{e, i} \cdot \sum_{i=1}^{n} \mathrm{MR}_{m, i}}{\sqrt{n\left(\sum_{i=1}^{n} \mathrm{MR}_{e, i}^{2}\right)-\left(\sum_{i=1}^{n} \mathrm{MR}_{e, i}\right)^{2}} \sqrt{n\left(\sum_{i=1}^{n} \mathrm{MR}_{m, i}^{2}\right)-\left(\sum_{i=1}^{n} \mathrm{MR}_{m, i}\right)^{2}}}\right]^{2}, \\
\mathrm{SSE} & =\frac{\sum_{i=1}^{n}\left(\mathrm{MR}_{e, i}-\mathrm{MR}_{m, i}\right)^{2}}{n}, \\
\mathrm{RMSE} & =\sqrt{\frac{\sum_{i=1}^{n}\left(\mathrm{MR}_{e, i}-\mathrm{MR}_{m, i}\right)^{2}}{n}}, \\
\chi^{2} & =\frac{\sum_{i=1}^{n}\left(\mathrm{MR}_{e, i}-\mathrm{MR}_{m, i}\right)^{2}}{n-c},
\end{aligned}
$$

where $\mathrm{MR}_{e, i}$ is the experimental moisture ratio, $\mathrm{MR}_{m, i}$ is the moisture ratio predicted from the model equation, $n$ is the number of data points, and $c$ is the number of constants in the model equation.

\section{Results and Discussion}

3.1. Drying Rate. The drying rate (DR) curves as a function of time at drying temperatures of 60,70 , and $80^{\circ} \mathrm{C}$ along with the standard error bars are shown in Figure 2.

At any given temperature, the drying rate decreased with time due to decrease in moisture content of the eggplant samples. Lower moisture content resulted in less movement of water to the surface and, therefore, less evaporation from the surface with time. The initial drying rate was observed to be highest at $80^{\circ} \mathrm{C}$ and lowest at $60^{\circ} \mathrm{C}$. This is because, for the same initial moisture content, higher air inlet temperature removed moisture at a faster rate. However, at later time instants, the drying rate at $60^{\circ} \mathrm{C}$ was higher than at $80^{\circ} \mathrm{C}$ since the moisture content in the sample was higher at $60^{\circ} \mathrm{C}$ compared to the moisture content at $80^{\circ} \mathrm{C}$ at the same time instant. The standard errors in Figure 2 are relatively small indicating good repeatability of the experiments.

3.2. Drying Curves. The drying curves (moisture ratio versus time) at drying temperatures of 60,70 , and $80^{\circ} \mathrm{C}$ along with the standard error bars are shown in Figure 3. The moisture ratio decreased with time at all drying temperatures. Similar trend was observed during drying of other food materials in fluidized bed $[6-13,48]$ and other types of dryers
[28, 49-55]. At any instant of time, moisture ratio was lower at higher drying temperature. Higher drying temperature also reduced the time for complete drying of the eggplant samples. Eggplant samples were completely dry after 30, 25 , and $20 \mathrm{~min}$ at drying temperature of 60,70 , and $80^{\circ} \mathrm{C}$, respectively. The equilibrium moisture content $\left(X_{e}\right)$ was zero for all the experimental runs. In addition, the experiment had good repeatability as indicated by the low values of standard error in Figure 3.

As depicted in Figure 4, drying of eggplant in the fluidized bed dryer was described only by the falling rate period. The increasing and constant rate periods were not observed. This is due to the fact that the fresh eggplant samples were free of surface moisture. During the drying process, only the moisture within the eggplants moved to surface and was then evaporated resulting in the falling rate period. In fact, the drying of most food materials is defined only by the falling rate period [13].

\subsection{Effective Moisture Diffusivity and Activation Energy.} The effective moisture diffusivity values were calculated for temperatures of 60,70 , and $80^{\circ} \mathrm{C}$ by plotting (7) as shown in Figure 5 . The diffusivity and $R^{2}$ values are tabulated in Table 1.

Compared to the previous studies on eggplant drying in other types of dryers [40, 41], higher moisture diffusivities were found in this study by using fluidized bed dryer and larger sample size. Effective moisture diffusivity values in the range 5.575-9.745 $\times 10^{-10} \mathrm{~m}^{2} / \mathrm{s}$ have been reported for eggplant drying in a cabinet dryer [41] while effective moisture diffusivity values in the range $0.93-8.84 \times 10^{-10} \mathrm{~m}^{2} / \mathrm{s}$ have 


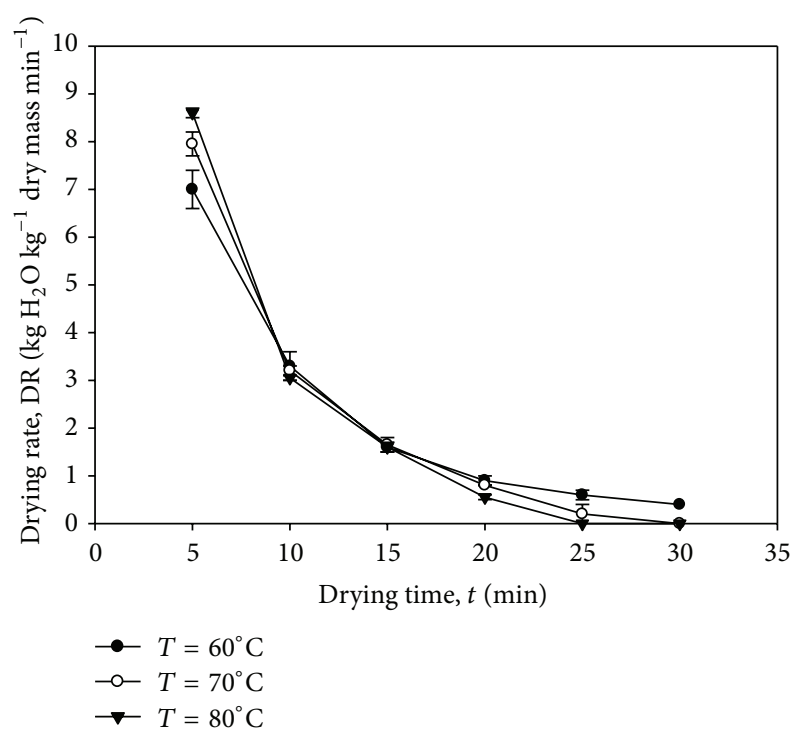

FIGURE 2: Experimental drying rate (DR) of eggplant versus drying time in the fluidized bed dryer at drying temperatures of 60,70 , and $80^{\circ} \mathrm{C}$. Air velocity kept constant at $3.10 \mathrm{~ms}^{-1}$.

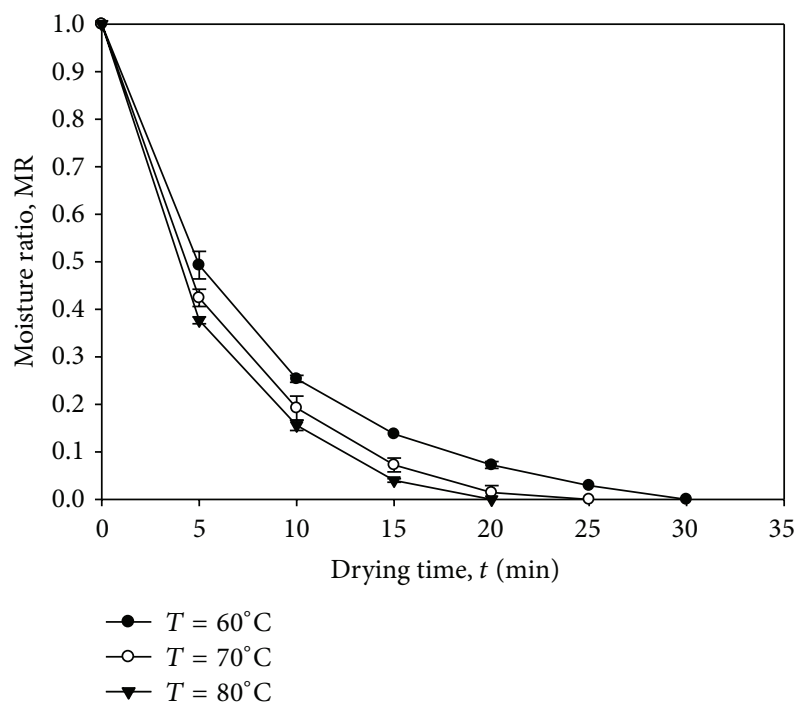

Figure 3: Experimental moisture ratio (MR) of eggplant versus drying time in the fluidized bed dryer at drying temperatures of 60 , 70 , and $80^{\circ} \mathrm{C}$. Air velocity kept constant at $3.10 \mathrm{~ms}^{-1}$.

been reported during convective drying within a temperature range of $50-80^{\circ} \mathrm{C}[40]$. As tabulated in Table 1 , the effective moisture diffusivities in this study were found to be in the range $2.667-4.311 \times 10^{-8} \mathrm{~m}^{2} / \mathrm{s}$ within the temperature range of $60-80^{\circ} \mathrm{C}$.

Using (8), The plot of $\ln \left(D_{e}\right)$ versus $1 / T$ exhibited a linear relationship (Figure 6) with a good fit quality $\left(R^{2}=0.9924\right)$. The activation energy $\left(E_{a}\right)$ and the preexponential factor $\left(D_{0}\right)$ were found to be $23.5 \mathrm{~kJ} \mathrm{~mol}^{-1}$ and $1.322 \times 10^{-4} \mathrm{~m}^{2} / \mathrm{s}$, respectively.

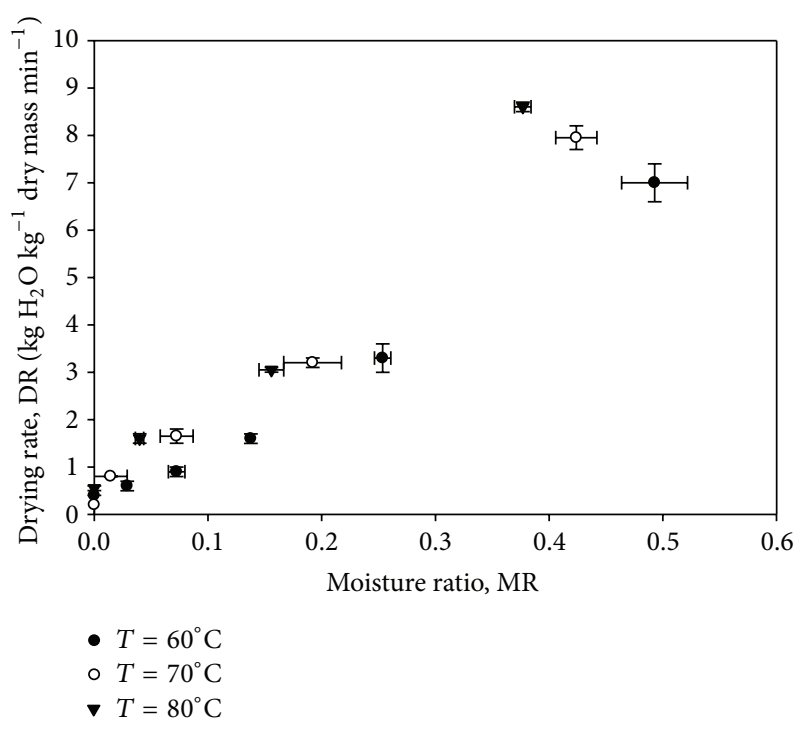

FIGURE 4: Drying rate (DR) versus moisture ratio (MR) at drying temperatures of 60,70 , and $80^{\circ} \mathrm{C}$. Air velocity kept constant at $3.10 \mathrm{~ms}^{-1}$

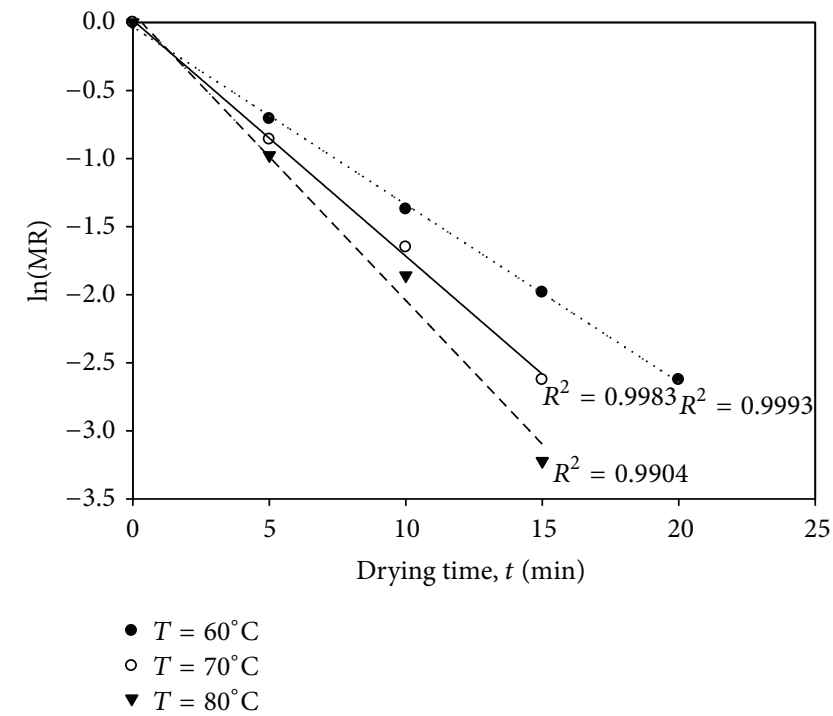

FIGURE 5: Experimental $\ln (\mathrm{MR})$ versus drying time at temperatures of 60,70 , and $80^{\circ} \mathrm{C}$.

TABLE 1: Effective moisture diffusivity $\left(D_{e}\right)$ values at different drying temperatures.

\begin{tabular}{lcc}
\hline Temperature, $T\left({ }^{\circ} \mathrm{C}\right)$ & $\begin{array}{c}\text { Effective moisture } \\
\text { diffusivity, } D_{e}\left(\mathrm{~m}^{2} / \mathrm{s}\right)\end{array}$ & $R^{2}$ \\
\hline 60 & $2.667 \times 10^{-8}$ & 0.9993 \\
70 & $3.541 \times 10^{-8}$ & 0.9983 \\
80 & $4.311 \times 10^{-8}$ & 0.9904 \\
\hline
\end{tabular}

The effect of temperature on effective moisture diffusivity was, thus, given by the following equation:

$$
D_{e}=1.322 \times 10^{-4} e^{-2830.7 / T},
$$


TABLE 2: Mathematical models used to describe the drying kinetics of eggplants [6].

\begin{tabular}{llcr}
\hline Model number & Model equation & Model name & Reference \\
\hline 1 & $\mathrm{MR}=e^{-k t}$ & Newton \\
2 & $\mathrm{MR}=a \cdot e^{-k t}$ & Henderson and Pabis \\
3 & $\mathrm{MR}=a \cdot e^{-k t}+b$ & Logarithmic & [57] \\
4 & $\mathrm{MR}=a \cdot e^{-k_{1} t}+b \cdot e^{-k_{2} t}$ & Two-term \\
5 & $\mathrm{MR}=a \cdot e^{-k t}+(1-a) \cdot e^{-a k t}$ & Two-term exponential \\
6 & $\mathrm{MR}=a \cdot e^{-k t}+(1-a) \cdot e^{-b k t}$ & Diffusion approach \\
7 & $\mathrm{MR}=e^{-k t^{n}}$ & Page & [60] \\
8 & $\mathrm{MR}=e^{-(k t)^{n}}$ & Modified Page \\
9 & $\mathrm{MR}=a \cdot e^{-(k t)^{n}}$ & Ademiluyi et al. \\
10 & $\mathrm{MR}=a \cdot e^{-(k t)^{n}}+b$ & Demir et al. \\
\hline
\end{tabular}

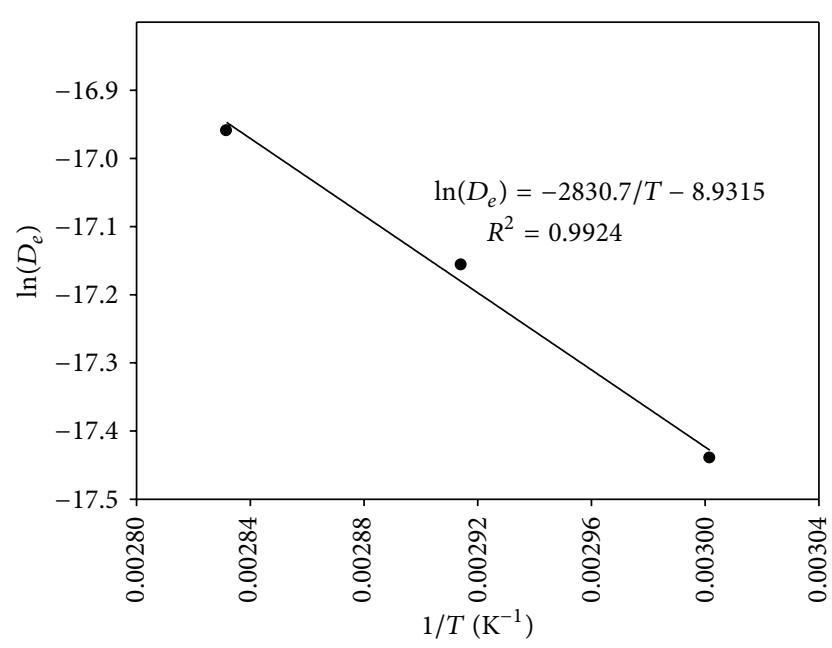

FIGURE 6: Linear relation between $\ln \left(D_{e}\right)$ and $1 / T$ at temperatures dictated by the Arrhenius-type relationship.

where $D_{e}$ has the unit $\mathrm{m}^{2} / \mathrm{s}$ and $T$ is the absolute temperature in $\mathrm{K}$.

\subsection{Mathematical Modelling and Statistical Analysis of Drying} Curves. The experimental drying kinetic data at each temperature was fitted to the ten different models summarized in Table 2. All these models contain the moisture ratio (MR) as the dependent variable and drying time $(t)$ as the independent variable. The models were fitted to the experimental moisture ratio data using nonlinear regression in MS Excel.

The values of model constants, coefficient of determination $\left(R^{2}\right)$, reduced sum square error (SSE), root mean square error (RMSE), and reduced Chi-square $\left(\chi^{2}\right)$ are summarized for each drying temperature in Table 3. In order to select the best model, the simple criteria of highest $R^{2}$ and lowest SSE, RMSE, and $\chi^{2}$ were used. All models fitted the experimental drying data very well with $R^{2} \geq 0.9990$ and reasonably low values of SSE, RMSE, and $\chi^{2}$. However, the model by Demir et al. [56] described the drying data with highest $R^{2}$ and lowest SSE, RMSE, and $\chi^{2}$ and, therefore, was selected as the best model to describe drying kinetics of eggplants in a fluidized bed dryer. Figure 7 shows a comparison between

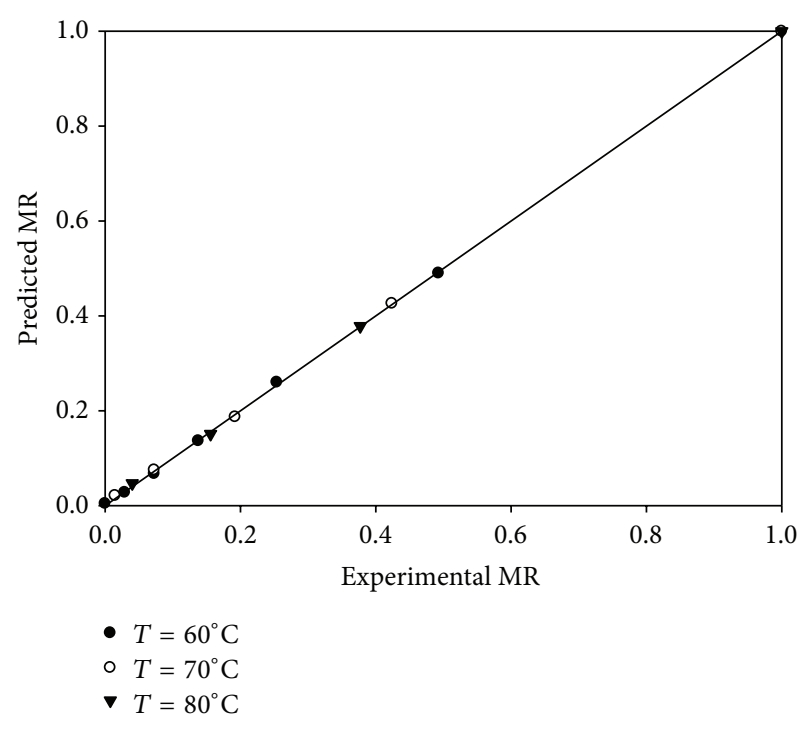

FIGURE 7: Comparison of experimental and predicted moisture ratio for model by Demir et al. [56].

the experimental moisture ratio values and the moisture ratio predicted from the model of Demir et al. [56].

3.5. Rehydration Test Results. After $24 \mathrm{~h}$ of rehydration in deionized water, the eggplant samples were found to have a rehydration ratio (RR) of 4.889 as given by (4). Based on the rehydration ratio, the final moisture content after rehydration was $3.889 \mathrm{~kg} \mathrm{H}_{2} \mathrm{O} \mathrm{kg}^{-1}$ dry mass. Thus, the eggplant samples rehydrated partially and not completely to their initial moisture content. This indicates good quality of the dried eggplant product from the fluidized bed dryer. In case of rehydration on exposure to moist ambient air for $24 \mathrm{~h}$, the rehydration ratio was found to be zero. This again indicates good quality of the dried product.

3.6. Comparison with Direct Sunlight Drying. In case of direct sunlight drying (temperature between 44 and $46^{\circ} \mathrm{C}$ ), the sample was dry completely after $4 \mathrm{~h}$. Compared to drying in fluidized bed dryer, direct sunlight drying took a longer period for complete drying. In addition, the color quality 
TABLE 3: Results of mathematical modelling and statistical analysis of the experimental moisture ratio data.

\begin{tabular}{|c|c|c|c|c|c|c|}
\hline$T\left({ }^{\circ} \mathrm{C}\right)$ & Model name & Model constants & $R^{2}$ & SSE & RMSE & $\chi^{2}$ \\
\hline \multirow{10}{*}{60} & Newton & $k: 0.1376$ & 0.9993 & $7.959 \times 10^{-5}$ & 0.0089 & $9.285 \times 10^{-5}$ \\
\hline & Henderson and Pabis & $k: 0.1373 ; a: 0.9972$ & 0.9993 & $7.836 \times 10^{-5}$ & 0.0089 & $1.097 \times 10^{-4}$ \\
\hline & Logarithmic & $k: 0.1373 ; a: 0.9972 ; b: 0$ & 0.9993 & $7.836 \times 10^{-5}$ & 0.0089 & $1.371 \times 10^{-4}$ \\
\hline & Two-term & $k_{1}: 4.303 ; k_{2}: 0.1325 ; a: 0.0427 ; b: 0.9573$ & 0.9995 & $6.066 \times 10^{-5}$ & 0.0078 & $1.415 \times 10^{-4}$ \\
\hline & Two-term exponential & $k: 0.1509 ; a: 0.7271$ & 0.9993 & $7.624 \times 10^{-5}$ & 0.0087 & $1.067 \times 10^{-4}$ \\
\hline & Diffusion approach & $k: 1.849 ; a: 0.0427 ; b: 0.0716$ & 0.9995 & $6.066 \times 10^{-5}$ & 0.0078 & $1.061 \times 10^{-4}$ \\
\hline & Page & $k: 0.1471 ; n: 0.9708$ & 0.9995 & $6.669 \times 10^{-5}$ & 0.0082 & $9.336 \times 10^{-5}$ \\
\hline & Modified Page & $k: 0.1389 ; n: 0.9708$ & 0.9995 & $6.669 \times 10^{-5}$ & 0.0082 & $9.336 \times 10^{-5}$ \\
\hline & Ademiluyi et al. & $k: 0.1387 ; n: 0.9713 ; a: 0.9994$ & 0.9995 & $6.664 \times 10^{-5}$ & 0.0082 & $1.166 \times 10^{-4}$ \\
\hline & Demir et al. & $k: 0.1301 ; n: 0.8906 ; a: 1.032 ; b:-0.0316$ & 0.9999 & $1.306 \times 10^{-5}$ & 0.0036 & $3.046 \times 10^{-5}$ \\
\hline \multirow{10}{*}{70} & Newton & $k: 0.1715$ & 0.9993 & $1.116 \times 10^{-4}$ & 0.0106 & $1.339 \times 10^{-5}$ \\
\hline & Henderson and Pabis & $k: 0.1716 ; a: 1.001$ & 0.9993 & $1.114 \times 10^{-4}$ & 0.0105 & $1.672 \times 10^{-4}$ \\
\hline & Logarithmic & $k: 0.1716 ; a: 1.001 ; b: 0$ & 0.9993 & $1.114 \times 10^{-4}$ & 0.0105 & $2.229 \times 10^{-4}$ \\
\hline & Two-term & $k_{1}: 4.303 ; k_{2}: 0.1751 ; a:-0.0267 ; b: 1.027$ & 0.9999 & $1.076 \times 10^{-4}$ & 0.0104 & $3.226 \times 10^{-4}$ \\
\hline & Two-term exponential & $k: 0.1898 ; a: 1.372$ & 0.9993 & $9.403 \times 10^{-5}$ & 0.0097 & $1.410 \times 10^{-4}$ \\
\hline & Diffusion approach & $k: 2.125 ; a:-0.0267 ; b: 0.0823$ & 0.9993 & $1.075 \times 10^{-4}$ & 0.0104 & $2.151 \times 10^{-4}$ \\
\hline & Page & $k: 0.1597 ; n: 1.034$ & 0.9993 & $9.856 \times 10^{-5}$ & 0.0099 & $1.478 \times 10^{-4}$ \\
\hline & Modified Page & $k: 0.1696 ; n: 1.034$ & 0.9993 & $9.856 \times 10^{-5}$ & 0.0099 & $1.478 \times 10^{-4}$ \\
\hline & Ademiluyi et al. & $k: 0.1695 ; n: 1.034 ; a: 0.9993$ & 0.9993 & $9.847 \times 10^{-5}$ & 0.0099 & $1.967 \times 10^{-4}$ \\
\hline & Demir et al. & $k: 0.1599 ; n: 0.9321 ; a: 1.032 ; b:-0.0326$ & 0.9999 & $1.876 \times 10^{-5}$ & 0.0043 & $5.627 \times 10^{-5}$ \\
\hline \multirow{10}{*}{80} & Newton & $k: 0.1951$ & 0.9991 & $1.567 \times 10^{-4}$ & 0.0125 & $1.958 \times 10^{-4}$ \\
\hline & Henderson and Pabis & $k: 0.1952 ; a: 1.001$ & 0.9991 & $1.567 \times 10^{-4}$ & 0.0125 & $2.609 \times 10^{-4}$ \\
\hline & Logarithmic & $k: 0.1952 ; a: 1.001 ; b: 0$ & 0.9991 & $1.567 \times 10^{-4}$ & 0.0125 & $3.914 \times 10^{-4}$ \\
\hline & Two-term & $k_{1}: 4.303 ; k_{2}: 0.2002 ; a:-0.0348 ; b: 1.035$ & 0.9990 & $1.516 \times 10^{-4}$ & 0.0123 & $7.580 \times 10^{-4}$ \\
\hline & Two-term exponential & $k: 0.2167 ; a: 1.382$ & 0.9991 & $1.380 \times 10^{-4}$ & 0.0117 & $2.300 \times 10^{-4}$ \\
\hline & Diffusion approach & $k: 2.272 ; a:-0.0348 ; b: 0.0881$ & 0.9990 & $1.152 \times 10^{-4}$ & 0.0123 & $3.790 \times 10^{-4}$ \\
\hline & Page & $k: 0.1807 ; n: 1.039$ & 0.9991 & $1.142 \times 10^{-4}$ & 0.0119 & $2.366 \times 10^{-4}$ \\
\hline & Modified Page & $k: 0.1926 ; n: 1.039$ & 0.9991 & $1.142 \times 10^{-4}$ & 0.0119 & $2.366 \times 10^{-4}$ \\
\hline & Ademiluyi et al. & $k: 0.1925 ; n: 1.039 ; a: 0.9995$ & 0.9991 & $1.419 \times 10^{-4}$ & 0.0119 & $3.548 \times 10^{-4}$ \\
\hline & Demir et al. & $k: 0.1743 ; n: 0.8725 ; a: 1.057 ; b:-0.0575$ & 0.9999 & $1.794 \times 10^{-5}$ & 0.0042 & $8.971 \times 10^{-5}$ \\
\hline
\end{tabular}

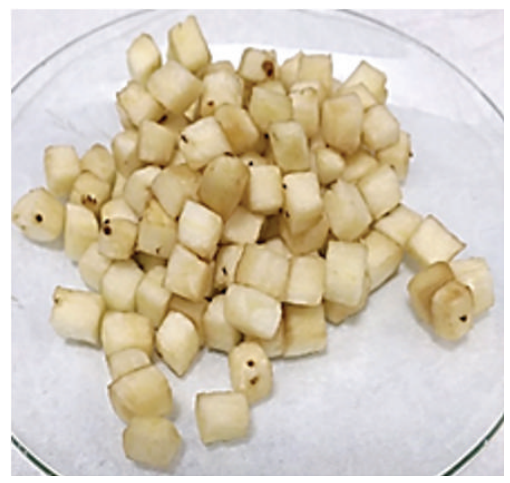

(a)

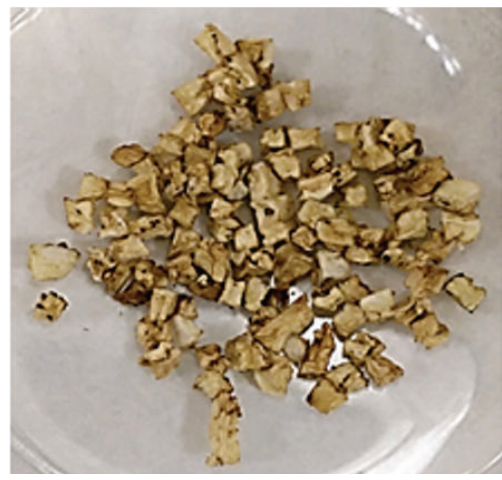

(b)

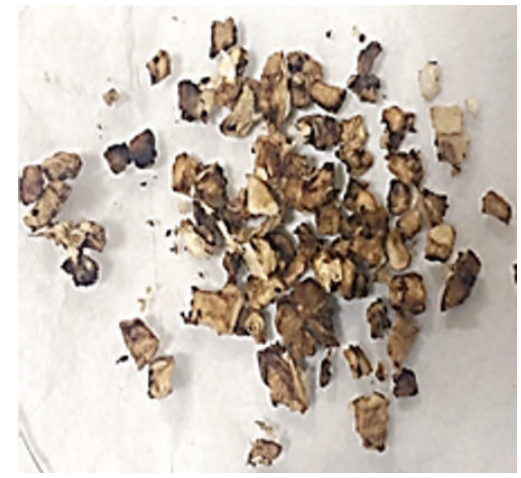

(c)

Figure 8: Comparison of color quality of (a) fresh eggplant sample, (b) dried product from fluidized bed dryer at $80^{\circ} \mathrm{C}$, and (c) dried product from direct sunlight drying. 
of the dried product was different for the two cases. Direct sunlight drying resulted in dried eggplant with a very poor color quality. This is due to high degree of burn caused by sunlight. Figure 8 shows a color comparison between the fresh eggplant sample and the dried samples from the fluidized bed dryer and direct sunlight drying.

As depicted in Figure 8, in terms of color quality, the product from the fluidized bed dryer was better when compared to the product from direct sunlight drying. In fact, fluidized bed dryer resulted in minimal color change of the product compared to the fresh eggplant sample.

\section{Conclusion}

In conclusion, drying of eggplants in the fluidized bed dryer was only described by the falling rate period. Both the drying rate and moisture ratio decreased with time. Higher drying temperature decreased the drying time and increased the effective moisture diffusivity. Although all the models considered fitted the experimental drying data very well, the model by Demir et al. showed the highest coefficient of determination and lowest values of reduced sum square error, root mean square error, and reduced Chi-square. Fluidized bed drying, therefore, provides a practical and feasible method for drying and preservation of eggplants while maintaining the qualitative characteristics such as low rehydration ratio and good color quality.

\section{Conflict of Interests}

The authors declare no conflict of interests.

\section{Acknowledgment}

The authors would like to appreciate the support of the Chemical Engineering Department at the American University of Sharjah.

\section{References}

[1] C. Ertekin and O. Yaldiz, "Drying of eggplant and selection of a suitable thin layer drying model," Journal of Food Engineering, vol. 63, no. 3, pp. 349-359, 2004.

[2] A. A. Akeredolu and L. O. Adebajo, "Microflora of three dehydrated vegetables," British Microbiology Research Journal, vol. 3, no. 3, pp. 295-308, 2013.

[3] V. R. Sagar and P. Suresh Kumar, "Recent advances in drying and dehydration of fruits and vegetables: a review," Journal of Food Science and Technology, vol. 47, no. 1, pp. 15-26, 2010.

[4] L.-L. Huang and M. Zhang, "Trends in development of dried vegetable products as snacks," Drying Technology, vol. 30, no. 5, pp. 448-461, 2012.

[5] U. S. Pal, M. K. Khan, and S. N. Mohanty, "Heat pump drying of green sweet pepper," Drying Technology, vol. 26, no. 12, pp. 1584-1590, 2008.

[6] A. Kaleta, K. Górnicki, R. Winiczenko, and A. Chojnacka, "Evaluation of drying models of apple (var. Ligol) dried in a fluidized bed dryer," Energy Conversion and Management, vol. 67, pp. 179-185, 2013.
[7] D. Velić, M. Bilić, S. Tomas, M. Planinić, A. Bucić-Kojić, and S. Jokić, "Study of the drying kinetic of 'Granny Smith' apple in fluid bed dryer," Agriculturae Conspectus Scientificus, vol. 72, no. 4, pp. 329-334, 2007.

[8] S. Meziane, "Drying kinetics of olive pomace in a fluidized bed dryer," Energy Conversion and Management, vol. 52, no. 3, pp. 1644-1649, 2011.

[9] H. R. Gazor and A. Mohsenimanesh, "Modelling the drying kinetics of canola in fluidised bed dryer," Czech Journal of Food Sciences, vol. 28, no. 6, pp. 531-537, 2010.

[10] S. Soponronnarit, T. Swasdisevi, S. Wetchacama, and W. Wutiwiwatchai, "Fluidised bed drying of soybeans," Journal of Stored Products Research, vol. 37, no. 2, pp. 133-151, 2001.

[11] M. J. Perea-Flores, V. Garibay-Febles, J. J. Chanona-Pérez et al., "Mathematical modelling of castor oil seeds (Ricinus communis) drying kinetics in fluidized bed at high temperatures," Industrial Crops and Products, vol. 38, no. 1, pp. 64-71, 2012.

[12] S. M. Tasirin, S. K. Kamarudin, J. A. Ghani, and K. F. Lee, "Optimization of drying parameters of bird's eye chilli in a fluidized bed dryer," Journal of Food Engineering, vol. 80, no. 2, pp. 695-700, 2007.

[13] A. Vega, P. Fito, A. Andrés, and R. Lemus, "Mathematical modeling of hot-air drying kinetics of red bell pepper (var. Lamuyo)," Journal of Food Engineering, vol. 79, no. 4, pp. 14601466, 2007.

[14] M. S. Hatamipour and D. Mowla, "Shrinkage of carrots during drying in an inert medium fluidized bed," Journal of Food Engineering, vol. 55, no. 3, pp. 247-252, 2002.

[15] S. J. Temple and A. J. B. van Boxtel, "Modelling of fluidizedbed drying of black tea," Journal of Agricultural Engineering Research, vol. 74, no. 2, pp. 203-212, 1999.

[16] D. Bayrock and W. M. Ingledew, "Fluidized bed drying of baker's yeast: moisture levels, drying rates, and viability changes during drying," Food Research International, vol. 30, no. 6, pp. 407-415, 1997.

[17] C. Niamnuy and S. Devahastin, "Drying kinetics and quality of coconut dried in a fluidized bed dryer," Journal of Food Engineering, vol. 66, no. 2, pp. 267-271, 2005.

[18] A. Topuz, M. Gur, and M. Z. Gul, "An experimental and numerical study of fluidized bed drying of hazelnuts," Applied Thermal Engineering, vol. 24, no. 10, pp. 1535-1547, 2004.

[19] C. Srinivasakannan and N. Balasubramanian, "Estimation of diffusion parameters in fluidized bed drying," Advanced Powder Technology, vol. 20, no. 4, pp. 390-394, 2009.

[20] J. S. Cohen and T. C. S. Yang, "Progress in food dehydration," Trends in Food Science and Technology, vol. 6, no. 1, pp. 20-25, 1995.

[21] T. Nazghelichi, M. H. Kianmehr, and M. Aghbashlo, "Thermodynamic analysis of fluidized bed drying of carrot cubes," Energy, vol. 35, no. 12, pp. 4679-4684, 2010.

[22] Z. V. P. Murthy and D. Joshi, "Fluidized bed drying of aonla (Emblica officinalis)," Drying Technology, vol. 25, no. 5, pp. 883889, 2007.

[23] W. Senadeera, B. R. Bhandari, G. Young, and B. Wijesinghe, "Influence of shapes of selected vegetable materials on drying kinetics during fluidized bed drying," Journal of Food Engineering, vol. 58, no. 3, pp. 277-283, 2003.

[24] T. Madhiyanon, A. Phila, and S. Soponronnarit, "Models of fluidized bed drying for thin-layer chopped coconut," Applied Thermal Engineering, vol. 29, no. 14-15, pp. 2849-2854, 2009. 
[25] A. Lozano-Acevedo, M. Jimenez-Fernández, A. RagazzoSánchez, G. R. Urrea-Garcia, and G. Luna-Solano, "Fluidized bed drying process of thinly sliced potato (Solanum tuberosum)," American Journal of Potato Research, vol. 88, no. 4, pp. 360-366, 2011.

[26] S. J. Babalis and V. G. Belessiotis, "Influence of the drying conditions on the drying constants and moisture diffusivity during the thin-layer drying of figs," Journal of Food Engineering, vol. 65, no. 3, pp. 449-458, 2004.

[27] D. G. Mercer, A Basic Guide to Drying Fruits and Vegetables, University of Guelph, Ontario, Canada, 2012.

[28] M. K. Krokida, V. T. Karathanos, Z. B. Maroulis, and D. Marinos-Kouris, "Drying kinetics of some vegetables," Journal of Food Engineering, vol. 59, no. 4, pp. 391-403, 2003.

[29] C. Srinivasakannan and N. Balasubramaniam, "An experimental and modeling investigation on drying of ragi (Eleusine corocana) in fluidized bed," Drying Technology, vol. 24, no. 12, pp. 1683-1689, 2006.

[30] L. Mayor and A. M. Sereno, "Modelling shrinkage during convective drying of food materials: a review," Journal of Food Engineering, vol. 61, no. 3, pp. 373-386, 2004.

[31] T. Aktas, S. Fujii, Y. Kawano, and S. Yamamoto, "Effects of pretreatments of sliced vegetables with trehalose on drying characteristics and quality of dried products," Food and Bioproducts Processing, vol. 85, no. 3, pp. 178-183, 2007.

[32] A. A. Adedeji, T. K. Gachovska, M. O. Ngadi, and G. S. V. Raghavan, "Effect of pretreatments on drying characteristics of okra," Drying Technology, vol. 26, no. 10, pp. 1251-1256, 2008.

[33] U. Yucel, H. Alpas, and A. Bayindirli, "Evaluation of high pressure pretreatment for enhancing the drying rates of carrot, apple, and green bean," Journal of Food Engineering, vol. 98, no. 2, pp. 266-272, 2010.

[34] R. P. F. Guiné and M. J. Barroca, "Effect of drying treatments on texture and color of vegetables (pumpkin and green pepper)," Food and Bioproducts Processing, vol. 90, no. 1, pp. 58-63, 2012.

[35] C. O. Rovedo, C. Suarez, and P. E. Viollaz, "Drying of foods: evaluation of a drying model," Journal of Food Engineering, vol. 26, no. 1, pp. 1-12, 1995.

[36] A. A. El-Sebaii, S. Aboul-Enein, M. R. I. Ramadan, and H. G. El-Gohary, "Empirical correlations for drying kinetics of some fruits and vegetables," Energy, vol. 27, no. 9, pp. 845-859, 2002.

[37] Food and Agriculture Organization, "Crops: production quantities by country," 2015, http://faostat3.fao.org/browse/Q/QC/E.

[38] Food and Agriculture Organization, "Crops: Trade/Crops and livestock products,” August 2015, http://faostat3.fao.org/browse/ $\mathrm{T} / \mathrm{TP} / \mathrm{E}$.

[39] J. V. Santacatalina, C. Ozuna, J. A. Carcel, J. V. Garcia-Perez, and A. Mulet, "Quality assessment of dried eggplant using different drying methods: hot air drying, vacuum freeze drying and atmospheric freeze drying," in Proceedings of the 11th International Congress on Engineering and Food, Athens, Greece, May 2011.

[40] I. Doymaz, "Drying of eggplant slices in thin layers at different air temperatures," Journal of Food Processing and Preservation, vol. 35, no. 2, pp. 280-289, 2011.

[41] I. Doymaz and E. Göl, "Convective drying characteristics of eggplant slices," Journal of Food Process Engineering, vol. 34, no. 4, pp. 1234-1252, 2011.

[42] L. Wu, T. Orikasa, Y. Ogawa, and A. Tagawa, "Vacuum drying characteristics of eggplants," Journal of Food Engineering, vol. 83, no. 3, pp. 422-429, 2007.
[43] J. V. García-Pérez, C. Ozuna, C. Ortuño, J. A. Cárcel, and A. Mulet, "Modeling ultrasonically assisted convective drying of eggplant," Drying Technology, vol. 29, no. 13, pp. 1499-1509, 2011.

[44] Date \& Time, "Weather in Sharjah, Sharjah, United Arab Emirates," July 2015, http://www.timeanddate.com/weather/unitedarab-emirates/sharjah/historic.

[45] K. Sacilik, "Effect of drying methods on thin-layer drying characteristics of hull-less seed pumpkin (Cucurbita pepo L.)," Journal of Food Engineering, vol. 79, no. 1, pp. 23-30, 2007.

[46] J. Crank, The Mathematics of Diffusion, Clarendon Press, Oxford, UK, 2nd edition, 1975.

[47] B. I. O. Ade-Omowaye, N. K. Rastogi, A. Angersbach, and D. Knorr, "Combined effects of pulsed electric field pre-treatment and partial osmotic dehydration on air drying behaviour of red bell pepper," Journal of Food Engineering, vol. 60, no. 1, pp. 8998, 2003.

[48] S. M. Tasirin, I. Puspasari, A. W. Lun, P. V. Chai, and W. T. Lee, "Drying of kaffir lime leaves in a fluidized bed dryer with inert particles: kinetics and quality determination," Industrial Crops and Products, vol. 61, pp. 193-201, 2014.

[49] Q. Chen, J. Bi, X. Wu, J. Yi, L. Zhou, and Y. Zhou, "Drying kinetics and quality attributes of jujube (Zizyphus jujuba Miller) slices dried by hot-air and short- and medium-wave infrared radiation," LWT-Food Science and Technology, vol. 64, no. 2, pp. 759-766, 2015.

[50] P. Udomkun, D. Argyropoulos, M. Nagle, B. Mahayothee, S. Janjai, and J. Müller, "Single layer drying kinetics of papaya amidst vertical and horizontal airflow," LWT-Food Science and Technology, vol. 64, no. 1, pp. 67-73, 2015.

[51] S. N. Rahman, R. Wahid, and N. A. Rahman, "Drying Kinetics of Nephelium Lappaceum (Rambutan) in a drying oven," Procedia-Social and Behavioral Sciences, vol. 195, pp. 27342741, 2015.

[52] S. Taghian Dinani, N. Hamdami, M. Shahedi, and M. Havet, "Mathematical modeling of hot air/electrohydrodynamic (EHD) drying kinetics of mushroom slices," Energy Conversion and Management, vol. 86, pp. 70-80, 2014.

[53] V. T. Karathanos and V. G. Belessiotis, "Sun and artificial air drying kinetics of some agricultural products," Journal of Food Engineering, vol. 31, no. 1, pp. 35-46, 1997.

[54] I. T. Toğrul and D. Pehlivan, "Modelling of drying kinetics of single apricot," Journal of Food Engineering, vol. 58, no. 1, pp. 23-32, 2003.

[55] R. K. Goyal, A. R. P. Kingsly, M. R. Manikantan, and S. M. Ilyas, "Mathematical modelling of thin layer drying kinetics of plum in a tunnel dryer," Journal of Food Engineering, vol. 79, no. 1, pp. 176-180, 2007.

[56] V. Demir, T. Gunhan, and A. K. Yagcioglu, "Mathematical modelling of convection drying of green table olives," Biosystems Engineering, vol. 98, no. 1, pp. 47-53, 2007.

[57] W. K. Lewis, “The rate of drying of solid materials," Journal of Industrial and Engineering Chemistry, vol. 13, no. 5, pp. 427-432, 1921.

[58] S. M. Henderson and S. Pabis, "Grain drying theory. I. Temperature effect on drying coefficient," Journal of Agricultural Engineering Research, vol. 6, pp. 169-174, 1961.

[59] A. Yagcioglu, A. Degirmencioglu, and F. Cagatay, "Drying characteristics of laurel leaves under different drying conditions," in Proceedings of the 7th International Congress on Agricultural Mechanization and Energy, Adana, Turkey, 1999. 
[60] S. M. Henderson, "Progress in developing the thin layer drying equation," Transactions of the ASAE, vol. 17, no. 6, pp. 1167-1168, 1974.

[61] Y. I. Sharaf-Eldeen, J. L. Blaisdell, and M. Y. Hamdy, "A model for ear corn drying," Transactions of the ASAE, vol. 23, no. 5, pp. 1261-1265, 1980.

[62] A. S. Kassem, "Comparative studies on thin layer drying models for wheat," in Proceedings of the 13th International Congress on Agricultural Engineering, Rabat, Morocco, February 1998.

[63] G. E. Page, "Factors influencing the maximum rates of air drying shelled corn in thin layers," July 2015, http://docs.lib.purdue .edu/dissertations/AAI1300089/.

[64] D. G. Overhults, G. M. White, H. E. Hamilton, and I. J. Ross, "Drying soybean with heated air," Transactions of the ASAE, vol. 16, no. 1, pp. 112-113, 1973.

[65] T. Ademiluyi, E. O. Oboho, and M. Owudogu, "Investigation into the thin layer drying models of Nigerian popcorn varieties," Leonardo Electronic Journal of Practices and Technologies, vol. 7, no. 13, pp. 47-62, 2008. 

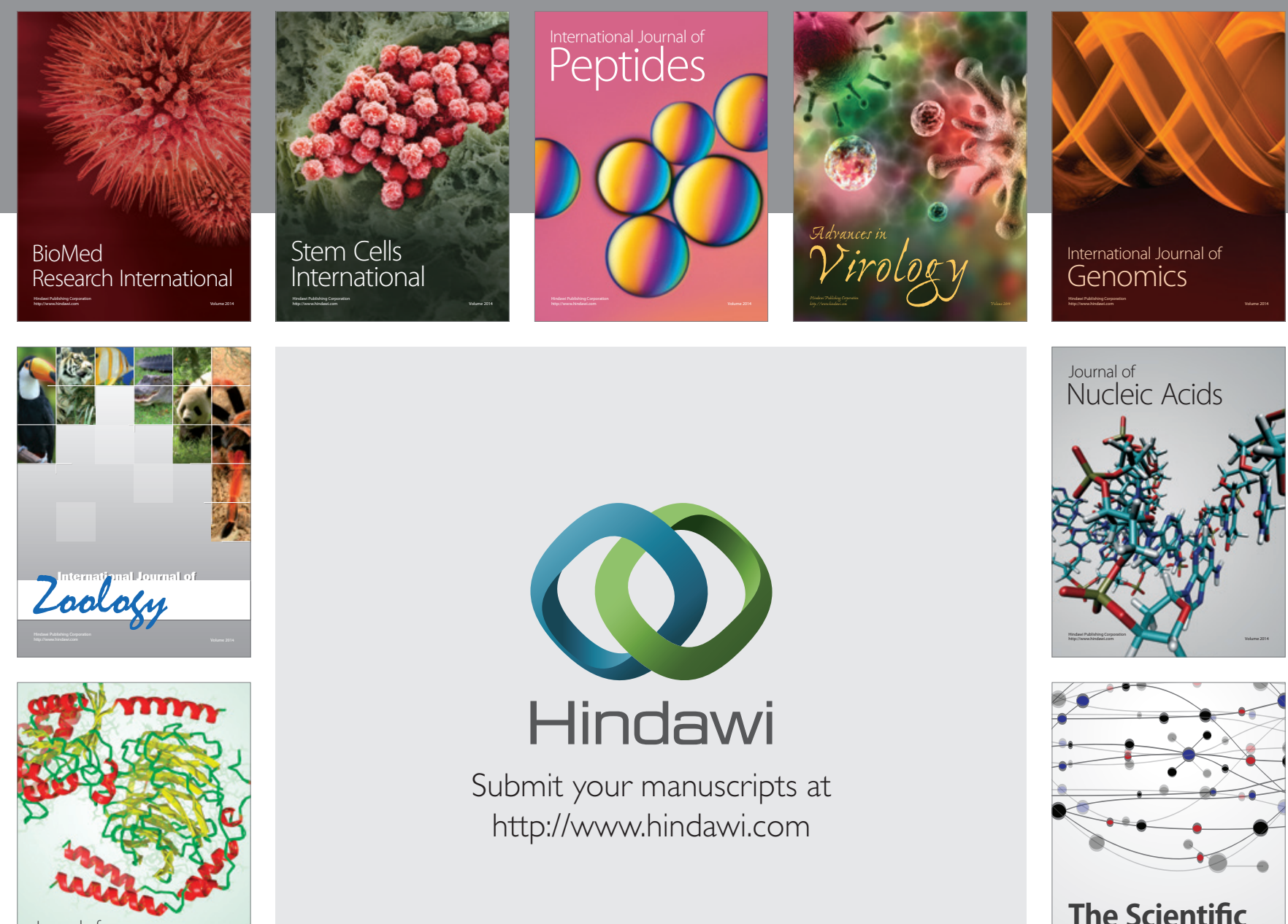

Submit your manuscripts at

http://www.hindawi.com

Journal of
Signal Transduction
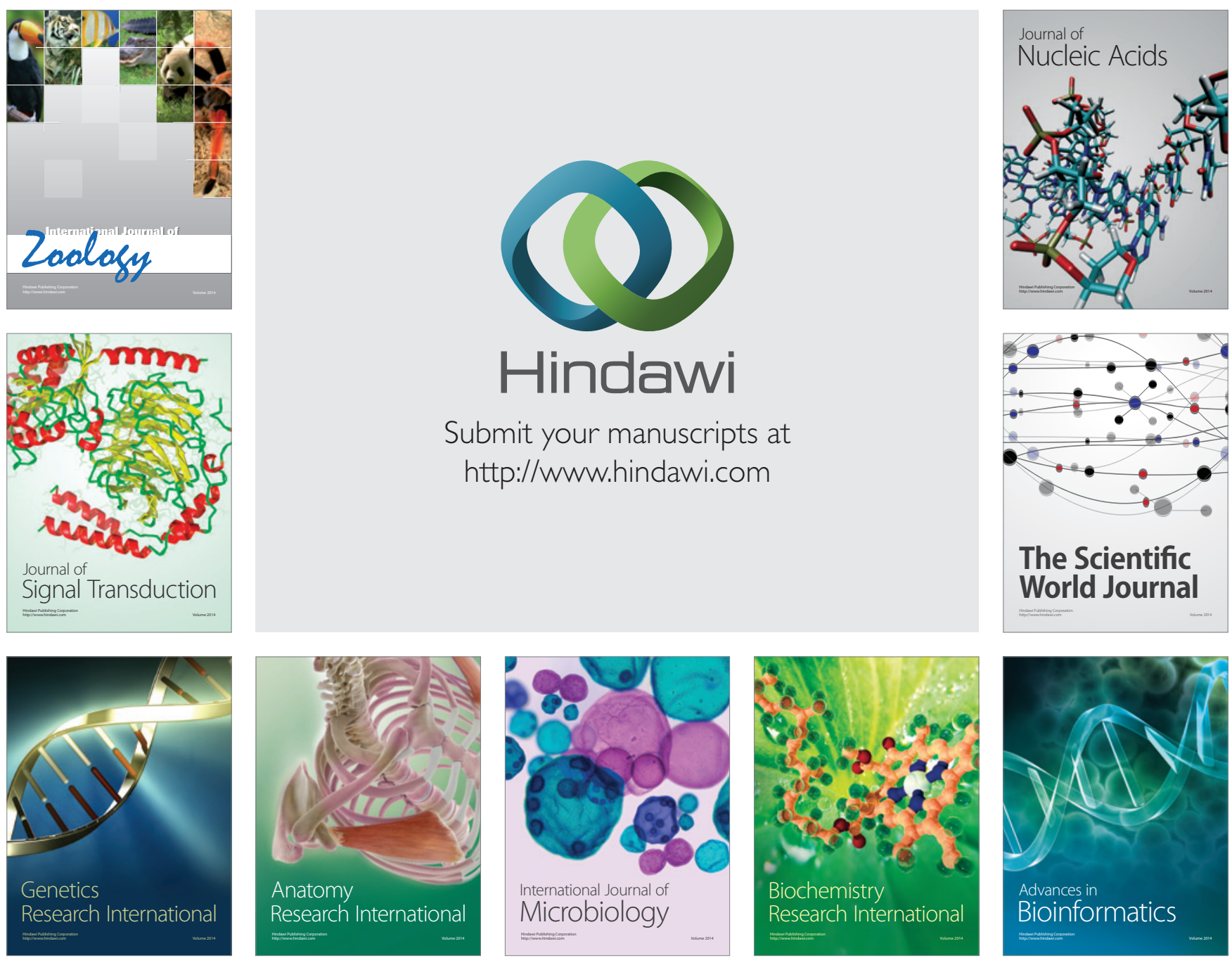

The Scientific World Journal
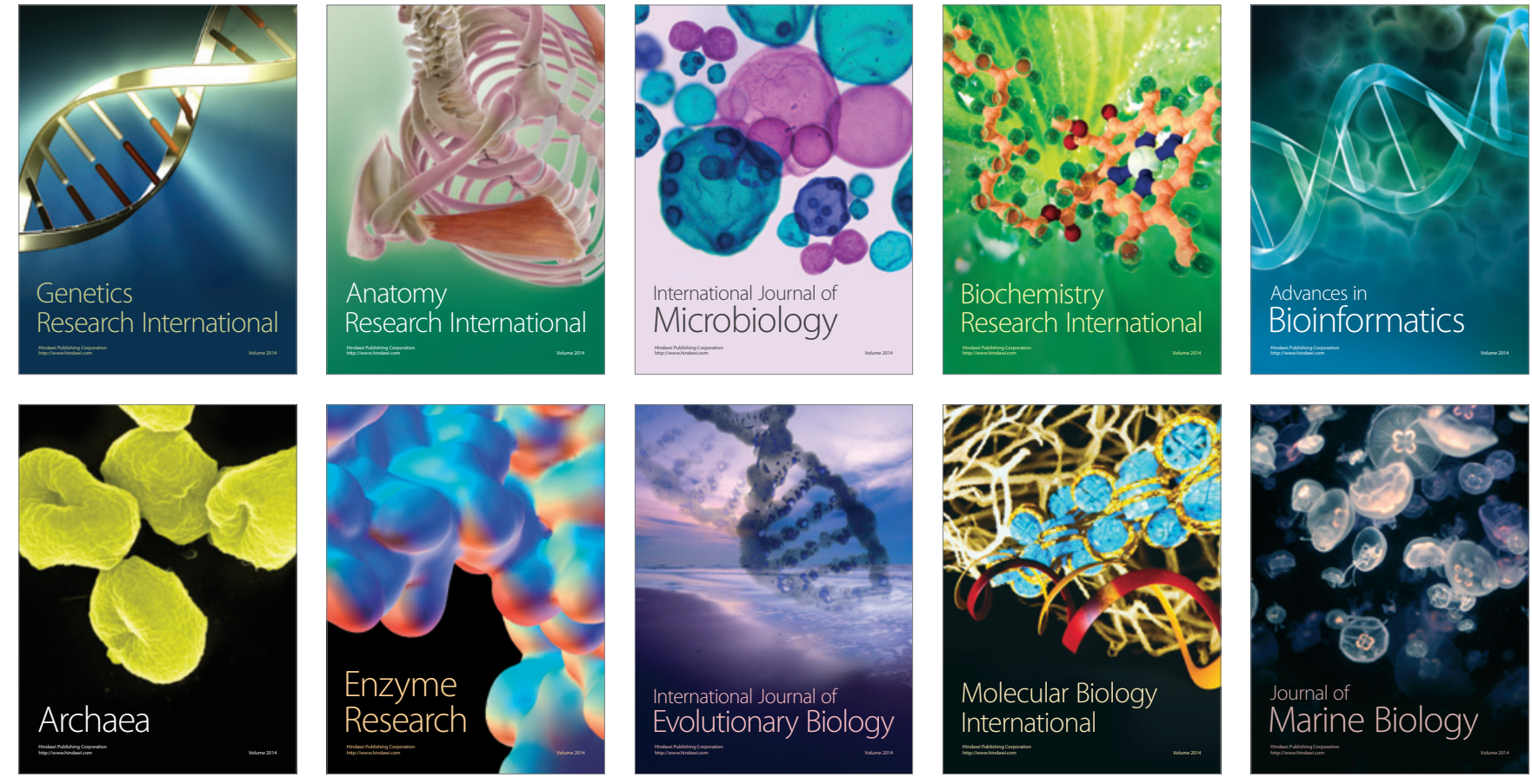